\title{
Determinasi Makroekonomi Terhadap Produk Pembiayaan Bank Islam Di Indonesia (Periode 2017 - 2019)
}

\author{
Fifi Hakimi, Nur Afifah Millatina, dan Sri Herianingrum \\ Universitas Airlangga \\ Email: fifihakimi94@gmail.com, Milea1903@gmail.com, sriheria@gmail.com \\ Diterima: November 2019; Dipublikasikan Januari 2020
}

\begin{abstract}
ABSTRAK
Penelitian ini bertujuan untuk mengetahui beberapa faktor makroekonomi seperti Indeks Harga onsumen, inflasi, interest rate, nilai tukar dan JII (sebagai Indeks Harga Saham Syariah) sebagai penentu produk pembiayaan Bank Syariah. Sampel data yang digunakan pada penelitian dikategorikan masih update, karena merupakan dari tiga periode terakhir pada tahun politik ini, maka dari itu penelitian ingin mencoba mengemukakan hasil dari beberapa faktor makroekonomi terhadapa penentuan produk pembiayaan, khususnya pada Bank Syariah. Model pada penelitian ini menggunakan Vector Error Correction Model (VECM). Penelitian ini menemukan bahwa faktor inflasi, interest rate, dan nilai tukar mempunyai hubungan yang positif signifikan terhadap penentu produk pembiayaan Bank Syariah Indonesia. Sedangkan faktor Indeks Harga Konsumen dan JII tidak mempunyai hubungan sebagai penentu produk pembiayaan Bank Syariah Indonesia.
\end{abstract}

Kata Kunci: makroekonomi; produk pembiayaan bank syariah; VECM.

\begin{abstract}
This study aims to determine several macroeconomic factors such as the index price index, inflation, interest rates, exchange rates, and JII (as Sharia Stock Price Index) as a determinant of Islamic bank financing products. The sample data used in this research is categorized as being updated, because it is from the last three periods of this political year, therefore the research wants to try to present the results of several macroeconomic factors regarding the determination of financing products, especially in Islamic banks. The model in this study uses the Vector Error Correction Model (VECM). This study found that factors of inflation, interest rates, and exchange rates have a significant positive relationship to the determinants of Bank Syariah Indonesia's financing products. While the Consumer Price Index factor and JII have no relationship as a determinant of Bank Syariah Indonesia's financing products.
\end{abstract}

Keywords: macroeconomics, sharia bank financing products, VECM. 


\section{PENDAHULUAN}

Setiap tahun pertumbuhan ekonomi bertumbuh sangat pesat, seiring dengan itu perkembangan sistem perbankan di Indonesia pun berkembang pesat. Sistem perbankan di Indonesia menganut dual sistem, yaitu Bank Konvensional dan Islam. Dual sistem ini telah diterapkan sejak tahun 1992, yang dipelopori oleh Bank Muammalat sebagai bank pertama yang menggunakan sistem bagi hasil. Pada tahun 1998, pemerintah menyempurnakan UU No.7/ 1992 tersebut menjadi UU No. 10 Tahun 1998, yang menjelaskan bahwa terdapat dua sistem dalam perbankan Indonesia yaitu munculnya bank Islam. Bank Islam Indonesia berkembang sangat cepat, karena salah satu faktornya yaitu mayoritas penduduk Indonesia beragama Islam. Pada sistem perbankan syariah juga mengacu pada bank yang didasarkan pada hukum dan praktik Islam (Syariah), yang sepenuhnya melarang aktivitas bunga dan perdagangan yang terdapat unsur- unsur haram dalam hukum Syariah Islam. Bank Islam beroperasi berdasarkan prinsip syariah diharapkan untuk menhasilkan dan menguncurkan dana berdasarkan perjanjian tertentu, termasuk perjanjian dalam bagi hasil, yang mana keuntungan dari dana pembiayaan nasabah (ataupun pinjaman kepada nasabah) dan pembiayaan antara bank ke bank lainnya keuntungannya dibagi rata. Dengan kata lain, peminjam dan pemberi pinjaman yang terlibat dalam transaksi keuangan syariah pada dasarnya terlibat dalam pembiayaan usaha, dengan itu perbankan Islam berbagi keuntungan dan risiko yang terkait terhadap nasabah (Solarin, 2018).

Terdapat kegiatan yang sama antara bank konvensional dan bank Islam, dimana diantara mereka menawarkan tabungan dan pinjaman kepada para nasabah. Namun, bank konvensional sangat bergantung pada pinjaman yang pada dasarnya digunakan untuk menciptakan lebih banyak keuntungan melalui suku bunga, sedangkan bank Islam berbasiskan dengan etika Islam yang mana pembiayaan pinjamannya suku bunga tidak dibebankan. Dalam dual sistem perbankan ini, dalam kemampuan yang dimiliki bank konvensional dan Islam ini didedikasikan untuk memberikan pelayanan yang terbaik para nasabah agar bertahan dalam kondisi ekonomi yang tidak pasti saat ini (Setyowati, 2019). Dengan dual sistem ini, para nasabah dapat memilih dengan mudah sesuai dengan minat mereka dalam menggunakan produk- produk bank.

Meskipun pangsa pasar perbankan syariah di Indonesia relatif kecil sekitar 5\% pada tahun 2016, industri ini menunjukkan tingkat pertumbuhan yang lebih cepat dibandingkan dengan bank konvensional. Selama bertahun-tahun, sektor perbankan Islam telah tumbuh dengan kecepatan dua digit, mencapai puncaknya pada 2011 setelah mencatat kenaikan total aset sebesar $50 \%$. Sejak itu, persentase tingkat pertumbuhan mulai menurun menjadi $34,1 \%$, 24,2\%, dan $12,4 \%$ masing-masing pada tahun 2012 , 2013, dan 2014. Gejolak ekonomi makro juga telah dikaitkan dengan tingkat pertumbuhan yang menurun ini, dan pada gilirannya telah secara signifikan mempengaruhi pertumbuhan industri secara keseluruhan. Ini termasuk inflasi harga listrik dan bensin menjelang akhir 2014, depresiasi signifikan Rupiah Indonesia sepanjang 2015, penurunan indeks saham Indonesia, dan masalah sosial-politik terkait dengan badan anti-korupsi yang tampaknya melemah (Alwyni 2011).

Peristiwa negatif ekonomi makro juga dapat memberikan efek perlambatan dalam perbankan Islam. Hal ini dapat ditunjukan pada volatilitas nilai tukar yang berlebihan juga dapat merusak stabilitas ekonomi dan keuangan di suatu negara, dan terbukti sangat berperan penting dalam mendorong krisis perbankan (Lindgren, 1996), dan meningkatnya inflasi mengurangi tingkat pengembalian rill atas aset bank dan mendorong penjatahan pinjaman (Bohachova, 2008). Secara teoritis, hubungan antara indikator ekonomi makro yang mempengaruhi aktivitas bank dapat dijelaskan oleh 
produksi industri, pasar saham, money supply, suku bunga, inflasi, dan nilai tukar. Produksi industri pada pasar saham mencerminkan siklus bisnis dan kondisi ekonomi di dalam negeri, siklus bisnis mefungsikan bank sebagai perantara dalam sektor rill. Oleh karena itu, risiko suku bunga yang terkait dengan perubahan suku bunga pasar merupakan sumber risiko pasar yang utama bagi bank.

Literatur empiris masa lalu dan baru-baru ini pada produk pembiyaan Syariah yang ditemukan pada penelitian Adebola (2011), Karim (2017) dan Setyowati (2019). Pada lieratur tersebut ada perbedaan pada penelitian ini, dimana penelitian ini menggunakan indicator makroekonomi yang lebih dari penelitian yang dilakukan oleh Setyowati (2019). Namun, focus penelitian ini dengan literasi tersebut terdapat focus yang sama dalam mengukur pengaruh produk pembiayaan.

Tujuan penelitian ini adalah untuk menyelidiki dampak factor-faktor yang menentukan produk pembiayaan perbankan Syariah di Indonesia dari Januari 2017 - Juni 2019. Kami berkontribusi dalam penelitian ini hanya untuk mengindentifikasi faktorfaktor makroekonomi yang mempengaruhi pembiayaan perbankan Islam di Indonesia. Faktor makroekonomi yang kami teliti adalah indikator Customer Index Price, Inflasi, Interest rate, Exchange Rate, index saham, yang mana terdapat beberapa variabel yang jarang digunakan dari literasi terdahulu yaitu Customer Index Price, dan Index Pasar Saham Syariah yang khususnya menggunakan JII (Jakarta Islamic Index).

\section{TINJAUAN PUSTAKA}

Setyowati (2019) membagi faktor- faktor yang mempengaruhi pembiayaan pada perbankan Syariah menjadi 5 kategori yaitu Indeks Harga Konsumen, Index Produksi Industri, Suku Bunga, Nilai Tukar, dan Jakarta Islamic Index. Penelitian ini terdapat tambahan variabel dari penelitian Setyowati (2019) yaitu variabel Inflasi, jadi variabel yang digunakan pada variabel ini adalah Indeks Harga Konsumen, Inflasi, Interest Rate, Nilai Tukar, dan Jakarta Islamic Index.

Literatur ekonomi khususnya perbankan kaya dengan berbagai aspek pinjaman dan kredit, mereka menggunakan berbagai faktor penentu dalam produk pinjaman tentunya di bank konvensional, namun masih sangat sedikit penelitian yang membahas pembiayaan atau pinjaman bank Syariah. Khususnya, pinjaman bank dalam perbankan konvensional dipengaruhi oleh variabel ekonomi makro dan mikro. . Faktor-faktor ekonomi mikro lainnya termasuk likuiditas dan kualitas aset. Di sisi lain, faktor makroekonomi merujuk pada variabel di seluruh negara, yang meliputi variabel moneter - jumlah uang beredar dan suku bunga, pertumbuhan ekonomi, tingkat inflasi, nilai tukar, dan indeks pasar saham, di antara variabel lainnya. Studi tentang penentu ekonomi mikro pinjaman bank termasuk Chernykh \& Theodossiou (2011) yang menggunakan rasio pinjaman bisnis jangka panjang bank terhadap total aset untuk mengukur pinjaman bank di Rusia. Studi ini menunjukkan bahwa pinjaman bank dipengaruhi secara positif oleh ukuran bank, kapitalisasi bank dan volume penyisihan kerugian yang dibuat oleh bank, tetapi gagal menemukan bukti untuk jenis kepemilikan bank. Dalam penelitian lain tentang faktor-faktor penentu ekonomi makro dari pinjaman bank, Du (dalam Setyowati, 2019) menyelidiki hubungan antara masalah pinjaman jangka panjang dan variabel ekonomi makro di Tiongkok untuk periode 1994 hingga 2005. Studi ini berpendapat bahwa tingkat pertumbuhan ekonomi saat ini dan percepatan industrialisasi menstimulasi permintaan pinjaman jangka menengah dan panjang. Inflasi terbukti memiliki efek ambang batas dengan tingkat inflasi yang lebih rendah yang berdampak positif pada pinjaman jangka menengah dan panjang, sementara tingkat inflasi yang tinggi 
berdampak negatif pada pinjaman jangka menengah dan panjang. Ada juga penelitian tentang faktor-faktor penentu pinjaman bank di negara-negara Afrika. Sebagai contoh, Mabutor (2010) menilai hubungan antara perilaku pinjaman bank, volatilitas nilai tukar dan fluktuasi harga saham. Bukti menunjukkan bahwa volatilitas nilai tukar dan fluktuasi harga ekuitas mempengaruhi perilaku bank-bank di Nigeria tetapi efeknya tidak signifikan. Namun, Kim \& Moreno (1994) mengevaluasi harga saham dan perilaku pinjaman bank di Jepang dan mengamati bahwa perubahan harga saham secara positif mempengaruhi volume pinjaman di Jepang, khususnya, dalam periode pasar pinjaman pasca- liberalisasi.

Penelitian lainnya menggunakan faktor ekonomi makro seperti jumlah uang beredar, tingkat bunga, pertumbuhan ekonomi, tingkat inflasi, nilai tukar, dan indeks pasar saham telah lebih banyak dipelajari dalam literatur ekonomi seperti yang dilakukan oleh (Kim dan Moreno, 1994; Pruteanu-Podpiera, 2007; Ibrahim, 2006; Pham, 2015). Sedangkan variabel ekonomi mikro yang paling sering digunakan sebagai faktor penentu adalah bank size, bank capital, collateral, rasio modal, penyisihan kerugian, likuiditas, dan kualitas asset (Karim, 2017; Chernykh dan Theodossiou, 2011; Cowling dan Westhead, 1996).

Sejumlah studi yang relatif terbatas telah menyelidiki nilai pembiayaan bank syariah. Studi yang dilakukan oleh Adebola (2011) menunjukkan bahwa suku bunga konvensional secara signifikan mempengaruhi pembiayaan bank syariah di Malaysia, yang menunjukkan bahwa pembiayaan bank syariah adalah sebagai pelengkap ataupun pengganti dari pembiayaan konvensional. Penelitian lainnya oleh Nursyamsiah (2017), yang mana terdapat hubungan pada pembiayaan perbankan syariah terhadap output riil, tingkat harga, tingkat suku bunga, dan perdagangan.

Selanjutnya, pada penelitian Kusumawati (2013) bahwasannya pembiayaan sektor kontruksi dipengaruhi positif oleh suku bunga, Index Production (IP), tingkat Inflasi, dan equivalent rate pembiayaan (ERP). Hal ini sejalan dengan hasil penelitian Suryadi (2013) bahwasnnya Industrial Production Index (IPI), suku bunga kredit (SBK) dan equivalent rate pembiayaan (ERP) berpengaruh positif signifikan terhadap rasio pembiayaan bank Islam, sedangkan variabel Dana Pihak Ketiga (DPK), pembiayaan bermasalah (NPF), bonus SBI Syariah (BSBIS), dan Inflasi berpengaruh negatif terhadap rasio pembiayaan bank Islam.

Mengingat keterbatasan penelitian sebelumnya, penelitian ini menyelidiki peran indeks harga konsumen, inflasi, interest rate, nilai tukar riil rupiah Indonesia terhadap dolar Amerika Serikat (AS), dan Jakarta Islamic Index, yang merupakan pengukuran pengaruh pasar saham Syariah di Indonesia pada pembiayaan bank syariah. Hal ini penting dalam mengukur pembiayaan untuk mendapatkan gagasan yang jelas tentang industri perbankan syariah Indonesia.

\section{METODE PENELITIAN}

Dalam menyelidiki hubungan jangka Panjang dan jangka pendek antara produk pembiayaan bank Syariah dengan faktor makroekonomi, beberapa langkah metodologi dapat digunakan pada penelitian ini. Sering kali dalam analisis ekonomi dan keuangan, uji stasioneritas dilakukan untuk menentukan stasioneritas data series. Penelitian ini dimulai dengan mengeksplorasi sifat stasioneritas dengan menggunakan prosedur uji Augmented-Dickey-Fuller (ADF) (Dickey dan Fuller, 1981). Uji ini dilakukan pada langkah pertama tujuannya untuk menghindari regresi palsu yang merupakan problem 
common diantara variabel- variabel makroekonomi yang mana proses pembuatan datanya mengikuti trend waktu. Jika semua variabel sifatnya stasioneritas pada second difference, maka $F$-stastistic tidak valid karena didasarkan pada asumsi bahwa variabel harus stasioneritas pada level, first difference atau second difference.

Namun dalam pandangan ekonomi, variabel- variabel tersebut akan saling terintegrasi jika mereka memiliki hubungan jangka panjang atau keseimbangan antara satu sama lain (Bekhet \& Al-Smadi, 2015). Tes kointegrasi diterapkan untuk menentukan model mana yang akan cocok untuk penelitian ini. Estimasi simulasi hubungan long-run dan short-run, dan memungkinkan tes tentang keberadaan hubungan antara variabel- variabel untuk data stasioner pada level, first difference atau second difference. Persamaan (1) hubungan jangka panjang antara FDR dan variabel makroekonomi, kita tulis di bawah ini:

$F D R t=\beta 0+\beta 1 I H K 1+\beta 2 I N F t+\beta 3 I R t+\beta 4 L n E x c t+\beta 5 L n J I I t+\varepsilon t$

Perbedaan persamaan (1) sebagai akibat dari sifat nonstasioner dari variabel, maka menggunkana persamaan (2), persamaan pada FDR dinyatakan sebagai berikut: $\Delta F D R t=\beta 0+\beta 1 \Delta I H K 1+\beta 2 \Delta I N F t+\beta 3 \Delta I R t+\beta 4 \Delta L n E x c t+\beta 5 \Delta L n J I I t+\varepsilon t \ldots \ldots$

Dimana $\beta 0, \beta 1, \beta 2, \beta 3, \beta 4$, dan $\beta 5$ adalah parameter yang harus ditentukan, oleh $\mathrm{t}$ dan $\varepsilon$ yang mana masing- masing ditunjukan pada waktu dan tingkat error.

Dalam penelitian ini, FDR sebagai variabel endogen dari produk pembiayaan bank Syariah, dan semua variabel makroekonomi lainnya adalah variabel exogen. Dalam penelitian ini menggunakan data time series berbentuk laporan keuangan bulanan periode Januari 2017 - Juni 2019. Data laporan keuangan tersebut didapat dari beberapa sumber. Variabel FDR bersumberkan dari Otoritas Jasa Keuangan (https://ojk.go.id/); variabel IHK, inflasi, Interest Rate, dan Exchange Rate didapat dari Bank Indonesia (https://www.bi.go.id/); sedangkan variabel JII didapat dari website IDX (https://www.idx.co.id/). Dalam penelitian ini, untuk mendapatkan hasil yang konsisten dan efesien, terdapat dua variabel yang ditransformasikan menjadi logaritma natural (Ln) seperti exchange rate dan JII, hal ini dilakukan untuk mengurangi masalah heteroskedasitas dan untuk mendapatkan tingkat pertumbuhan variable.

Penelitian ini menganilisis data dengan cara mengelompokkan data berdasarkan variabel dan jenis responden, mentabulasi data berdasarkan variabel dari seluruh responden, menyajikan data tiap variabel yang diteliti, melakukan perhitungan untuk menjawab rumusan masalah, dan melakukan perhitungan untuk menuji hipotesis yang telah diajukan (Sugiyono, 2010).

\section{HASIL DAN PEMBAHASAN}

Tabel 1. Menunjukkan hasil matriks korelasi dari semua variabel yang digunakan dalam penelitian ini. Variabel IHK, Inflasi, interest rate, exchange rate, dan JII mempunyai korelasi terhadap FDR. Dapat dilihat juga bahwasannya variabel inflasi, exchange rate, dan JII memiliki korelasi negative yang kuat dengan FDR. Dari hasil ini dapat mendukung literatur yang ada bahwa IHK, inflasi, interest rate, exchange rate, dan JII adalah penentu penting untuk FDR. 
Tabel 1: Hasil Matriks Korelasi

\begin{tabular}{lllllll}
\hline Variabel & FDR & IHK & INF & IR & LnEXC & LnJII \\
\hline FDR & 1 & & & & & \\
IHK & -0.631 & 1 & & & & \\
INF & 0.650 & -0.764 & 1 & & & \\
IR & -0.215 & 0.773 & -0.593 & 1 & & \\
LnEXC & -0.485 & 0.777 & -0.682 & 0.734 & 1 & \\
LnJII & 0.063 & -0.515 & 0.442 & -0.622 & -0.782 & 1 \\
\hline Sumber: Data
\end{tabular}

Sumber: Data Diolah.

Uji Stasioner dan Cointegrasi

Uji Stasioner adalah langkah penting dalam menganalisis data time series. Tabel.2 menunjukkan bahwa semua variabel stasioner pada first deifference dalam intersep pada tingkat signifikan yang sama. Tes unit root digunakan pada level signifikansi $1 \%, 5 \%$, dan $10 \%$.

Tabel 2: Hasil Uji Stationer

\begin{tabular}{|l|l|l|l|}
\hline \multicolumn{5}{|l|}{ Intercept } & Level & \multicolumn{2}{l|}{} \\
\hline & IHK & 0.386 & Nonstationary \\
\hline & INF & -1.513 & Nonstationary \\
\hline & IR & -0.606 & Nonstationary \\
\hline & N_T & -1.354 & Nonstationary \\
\hline & JII & -1.608 & Nonstationary \\
\hline & FDR & -2.860 & Nonstationary \\
\hline \multirow{2}{*}{ Intercept } & First difference & & \\
\hline & IHK & $-2.798^{* *}$ & Stationary \\
\hline & INF & $-5.390^{* *}$ & Stationary \\
\hline & IR & $-3.251^{* *}$ & Stationary \\
\hline & I_T & $-6.254^{* *}$ & Stationary \\
\hline & JII & $-4.301^{* *}$ & Stationary \\
\hline & FDR & $-6.944^{* *}$ & Stationary \\
\hline
\end{tabular}

Catatan: ADF adalah Augmented Dickey-Fuller dari unit root test ***, menunjukkan sigifikansi dari masing-masing variabel pada level 5\%, dan $1 \%$.

Sumber: Data Diolah

Tabel.3 Hasil dari Johansen untuk Uji Kointegrasi

\begin{tabular}{|l|l|l|l|l|l|}
\hline \multicolumn{7}{|c|}{ At most 1* } & 0.932102 & 162.0160 & 69.81889 & 0.0000 & Cointegrated \\
\hline At most 2* & 0.850462 & 89.39274 & 47.85613 & 0.0000 & Cointegrated \\
\hline At most 3* & 0.658757 & 38.08724 & 29.79707 & 0.0044 & Cointegrated \\
\hline At most 4 & 0.256689 & 9.057883 & 15.49471 & 0.3601 & Noncointegrated \\
\hline At most 5 & 0.038092 & 1.048576 & 3.841466 & 0.3058 & Noncointegrated \\
\hline
\end{tabular}

Catatan: Trace test menunjukkan 4 cointegrasi pada level $5 \%$

Sumber : Data Diolah.

Menurut Shresta \& Bhatta (2018) bahwa data penelitian tentang variabel endogen dan variabel exogen sebagian bersifat stasioner pada level dan sebagian lainnya pada first difference maka menggunakan model ARDL. Namun jika seluruh variabel tidak 
stasioner pada level tetapi terkointegrasi, maka hal tersebut dapat menggunkan Vector Error Corection Model (VECM) (Tulak \& Utami, 2017). Menurut pembahasan sebelumnya, maka penelitian ini tetap menggunakan model VECM karena ada kointegrasi antar variabel.

\section{Pembahasan}

Tabel 4: Vector Error Correction Model (VECM

\begin{tabular}{|c|c|c|}
\hline & Coefficient & T-statistic \\
\hline Variabel & -1.703916 & -1.48193 \\
\hline IHK & $\mathbf{1 9 . 0 9 3 6 7}$ & $\mathbf{5 . 3 0 3 0 2}$ \\
\hline INF & $\mathbf{1 3 . 2 2 9 1 8}$ & $\mathbf{6 . 5 1 9 3 1}$ \\
\hline IR & $\mathbf{3 9 8 . 4 3 2 7}$ & $\mathbf{8 . 1 7 4 6 0}$ \\
\hline LnEXC & 1.325260 & 0.03781 \\
\hline LnJII & Short - run & -0.25974 \\
\hline CointEq1 & -0.008273 & -0.49931 \\
\hline D(IHK(-2)) & -0.635440 & 0.09075 \\
\hline D(INF(-2)) & 0.127150 & 0.75455 \\
\hline D(IR(-2)) & 2.278423 & 0.48163 \\
\hline D(LnEXC(-2)) & 9.976826 & -1.09047 \\
\hline D(LnJII(-1)) & -13.01976 & \\
\hline
\end{tabular}

Sumber: Data Diolah

Tabel 4. Menunjukkan bahwa estimasi VECM tentang adanya hubungan jangka Panjang pada IHK, Inflasi, interest rate, nilai tukar dan JII terhadap FDR di Indonesia. Pada Jangka Panjang kami menemukan bahwa terdapat tiga variabel secara signifikan seperti Inflasi, interest rate, dan nilai tukar. Namun, dilihat pada jangka pendek bahwa semua variabel exogen tidak berpengaruh pada variabel produk pembiayaan bank Syariah (FDR).

Hasil statistik menunjukkan bahwa pada jangka Panjang variabel IHK dan JII tidak terdapat hubungan pada produk pembiayaan. Hasil ini sejalan dengan penemuan Setyowati (2019) yang menggunakan Teknik VECM juga, menyatakan bahwa IHK dan pembiayaan ditunjukkan pada tidak terdapat hubungan, namun terdapat hubungannya pada produk tabungan bank. Dimana efek pembiayaan pada pembelian barang melalui skema Murabahah banyak diminati oleh nasabah, sehingga produk pembiayaan murabahah saja yang akan meningkat. Dengan hal ini, dapat disimpulkan oleh peneliti bahwa jika Indeks Harga Konsumsi naik akibat inflasi maka mayoritas dari nasabah memilih produk tabungan bank, dibandingkan untuk mengambil produk pembiayaan Bank Syariah. Dilihat dari sisi JII (Index Harga Saham Syariah) yang tidak mempunyai hubungan pada produk pembiayaan bank Syariah hal ini menunjukkan bahwa Indeks Harga Saham pada JII masih belum merubah efek volume pembiayaan pada Bank Syariah di Indonesia. Hal ini tidak sejalan dengan penemuan Setyowati (2019) yang mengemukakan bahwa Indeks Harga Saham naik akan mengakibat efek volume pembiayaan Bank Syariah menurun, karena adanya pengaruh oleh inflasi dan interest rate. Karena bank syariah dan saham syariah saling terkait satu sama lain, maka ketersediaan pendanaan untuk industri Islam akan meningkatkan laba, laba, dan indeks saham. Meningkatnya bisnis industri Islam akan meningkatkan indeks saham gabungan syariah, dan merupakan tanda bisnis yang baik dan kondisi ekonomi di dalam negeri. 
Dilihat pada jangka panjang juga, variabel inflasi berpengaruh positif signifikan pada FDR yang sebagai indikator produk pembiayaan bank Syariah. Hal ini menunjukkan bahwa inflasi Indonesia meningkat maka produk pembiayaan Bank Syariah pun meningkat. Peningkatan inflasi menurunkan daya beli masyarakat dan meningkat tingkat suku bunga. Hal ini juga akan menyebabkan permintaan masyarakat akan barang dan jasa menurun yang nantinya berdampak pada menurunnya produktivitas sektor usaha, dan berimbas pada menurunnya permintaan sektor usaha atas pembiayaan produktif. Tingkat Inflasi juga dapat meningkatkan jumlah pembiayaan yang dikeluarkan oleh bank, terutama untuk pembiayaan konsumtif seperti murabahah (Cahyono, 2009; Iqbal, 2013).

Begitu juga dengan variabel interest rate hasil dari long- run menunjukkan bahwa adanya hubungan positif signifikan terhadap produk pembiayaan bank Syariah. Hasil ini selaras dengan temuan Solarin (2011) dan Adebola (2011) yang menunjukkan interest rate mempengaruhi jumlah pembiayaan di Bank Islam Malaysia. Dengan adanya hal ini, dapat disimpulkan bahwa pembiayaan bank Syariah bersifat pelengkap saja dan bukan untu pengganti pembiayaan bank konvensional. Sebelum mengambil pinjaman dari bank, pemangku kepentingan bisnis akan menghitung semua biaya dan risiko yang terjadi dari itu. Memang, mereka akan membandingkan suku bunga dari bank konvensional dan biaya marjinal di Bank Syariah Indonesia dan memustukan yang mana dapat memberi mereka lebih banyak benefit. Variabel exchange rate dilihat pada tabel 4. yang menunujukkan bahwasannya terdapat hubungan yang positif signifikan terhadap produk pembiayaan bank Syariah. Hasil ini sejalan dengan Setyowati (2019) yang menyatakan bahwa nilai tukar menyebabkan efek pada pembiayaan bank Syariah. Hal ini dapat dilihat bahwa negara- negara berkembang seperti Indonesia tidak direkomendasikan menjadi rumah bagi para investor asing. Padahal investasi modal asing adalah kunci terpenting untuk menumbuhkan ekonomi dan bisnis di negara - negara berkembang. Akibatnya, peristiwa negatif seperti penurunan secara tiba- tiba pada mata uang domestic atau disebut juga devaluasi mata uang akan mengakibatkan peralihan modal asing dari negara tersebut. Hal ini akan menyebabkan masa sulit bagi pembisnis dan menyebabkan gagal bayar hutang dalam pembiayaan.

\section{Hasil Impulse Responses}

Kisah lengkap tentang interaksi antar variabel sistem mungkin tidak sepenuhnya diungkapakan oleh kausalitas Granger. Maka dari itu penelitian ini dilengkapi dengan penyajian impulse responses dari variabel exogen yang mempunyai hubungan pada produk pembiayaan. Tujuan impulse responses ini untuk mengetahui respon implus dari variabel satu pada variabel lainnya dalam suatu sistem yang melibatkan juga beberapa jumlah variabel lainnya.

Response to Cholesky One S.D. (d.f. adjusted) InnovationsResponse to Cholesky One S.D. (d.f. adjusted) Innovations
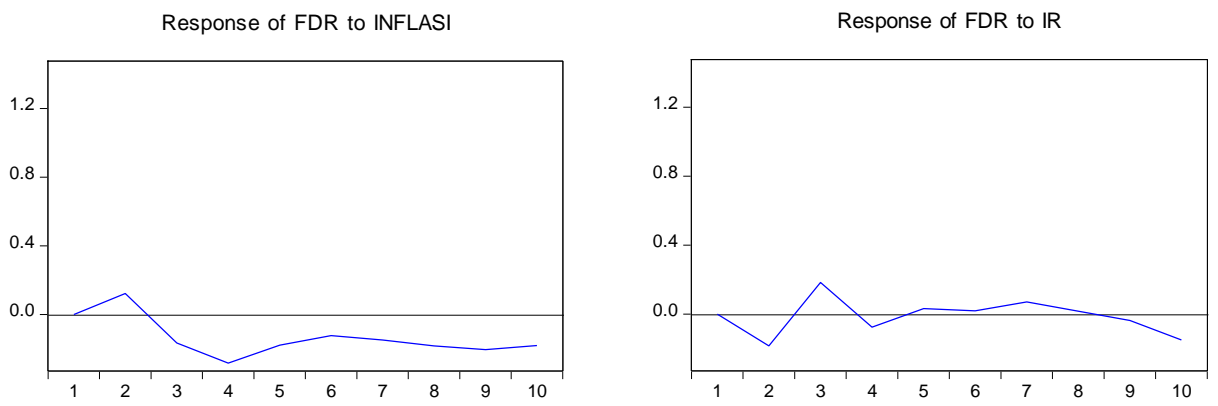
Response to Cholesky One S.D. (d.f. adjusted) Innovations

Response of FDR to NILAI_TUKAR

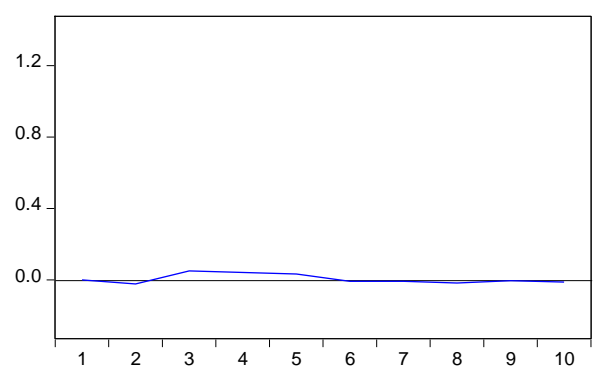

\section{Gambar 1. Respon FDR terhadap guncangan inflasi, interest rate, dan nilai tukar}

Dilihat pada gambar.1 menunjukkan bahwa peningkatan inflasi mendorong bankbank Islam untuk mengurangi pembiayaan, karena biaya pembiayaannya tinggi, dan sangat jarang konsumen yang mampu melakukan pembiayaan dalam kondisi ekonomi yang tidak stabil. Respon positif ke negative ditunjukkan pada interest rate dan nilai tukar. Hal ini menunjukkan adanya guncangan pada jangka panjang dari interest rate dan nilai tukar yang memberikan efek positif pada pembiayaan, sebelum beralih pada efek negatif untuk periode kedua dan kesepuluh dari interest rate dan nilai tukar.

\section{Kesimpulan}

\section{KESIMPULAN DAN SARAN}

Penelitian ini yang menggunakan model VECM, yang dapat melihat hubungan dari variabel makroekonomi terhadap pembiayaan bank Syariah dilihat dari jangka waktu panjang. Hasil dari penelitian ini menunjukkan bahwa adanya hubungan yang poditif pada inflasi, niali tukar dan interest rate terhadap pembiayaan bank Syariah, hal ini dapat dinyatakan bahwa pembiayaan bank Syariah di Indonesia saat ini hanya bersifat pelengkap saja dan bukan untu pengganti pembiayaan bank konvensional. Sebelum mengambil pinjaman dari bank, pemangku kepentingan bisnis akan menghitung semua biaya dan risiko yang terjadi dari itu. Memang, mereka akan membandingkan suku bunga dari bank konvensional dan biaya marjinal di Bank Syariah Indonesia dan memustukan yang mana dapat memberi mereka lebih banyak benefit. Hal tersebut juga berdampak pada penurunan investor asing masuk pada Indonesia, karena adanya peristiwa negatif seperti penurunan secara tiba- tiba pada mata uang domestic atau disebut juga devaluasi mata uang akan mengakibatkan peralian modal asing dari negara tersebut. Hal ini akan menyebabkan masa sulit bagi pembisnis dan menyebabkan gagal bayar hutang dalam pembiayaan. Sedangkan variabel IHK dan JII tidak berpengaruh terhadap pembiayaan Bank Syariah di Indonesia, hasil ini sejalan dengan penelitian Setyowati (2019).

\section{Saran}

Keterbatasan pada penelitian ini, adanya kurangnya pengujian dari beberapa indicator makroekonomi lainnya sebagai variabel penentu produk pembiayaan. Penelitian ini juga hanya berfokus pada Bank Syariah di Indonesia saja. Selain itu juga hanya menggunakan lima indicator penentu pembiayaan bank Syariah Indonesia. Harapan kedepannya, agar penelitian selanjutnya dapat menggunakan beberapa indicator makroekonomi lainnya yang tidak terdapat pada penelitian ini, seperti PDB, jumlah uang 
beredar, dan Indeks Produk Industri, dari beberapa negara yang mempunyai Bank Syariah dengan mempertimbangkan penggunaan model penelitian yang berbeda.

\section{DAFTAR REFERENSI}

Adebola, Solarin Sakiru,Wan SulaimanWan Yusoff, and Jauhari Dahalan. 2011. The impact of macroeconomic variables on Islamic Banks financing in Malaysia. Research Journal of Finance and Accounting 2: 22-32.

Alwyni, Farouk A. 2011. Islamic Banking in Indonesia Growth and Performance Review. Available online: www.isfire.net (accessed on 23 April 2019

Bohachova, Olga. 2008. The Impact of Macroeconomic Factors on Risks in the Banking Sector: A Cross-Country Empirical Assessment. Tübingen: Institut für AngewandteWirtschaftsforschung (IAW), p. 44

Cahyono, Ari. 2009. Pengaruh Indikator Makroekonomi terhadap Dana Pihak Ketiga dan Pembiayaan Bank Syariah Mandiri. Tesis Tidak Dipublikasi. Jakarta. PSTTI UI.

Chernykh, Lucy, and Alexandra K. Theodossiou. 2011. Determinants of bank long-term lending behavior: Evidence from Russia. Multinational Finance Journal 15: 193216.

Cowling, Marc, and Paul Westhead. 1996. Bank lending decisions and small firms: Does size matter? International Journal of Entrepreneurial Behavior \& Research 2: $52-$ 68.

$\mathrm{Du}, \mathrm{W}$. (2011), "The Investigation on the Relationship between the Problem of LongTerm Loan and Economic Growth" China Finance Review International, 1(2), 187198.

Gazhali, I. (2007). Analisis Multivariative dengan Program SPSS. Semarang: UNDIP.

Ghazali, I. (2006). Aplikasi Analisis Multivariate dengan Program SPSS. Semarang: Badan Penerbit Diponegoro.

Iqbal, Muhammad, 2013, ANALYSIS OF FACTORS AFFECTING MURABAHAH FINANCING IN SHARIAH COMMERCIAL BANK, International Conference for Emerging Makerkets.

Karim, Bakri Abdul, Zulkefly Abdul Karim, and Muhammad Hafiz Mohd Shukri. 2017. Determinants of Islamic Bank financing in Malaysia: An empirical study using linear and nonlinear ARDL model. Jurnal Ekonomi Malaysia 51: 15-22.

Kim, Sun Bae, and Ramon Moreno. 1994. Stock prices and bank lending behavior in Japan. Economic Review-Federal Reserve Bank of San Francisco 1: 31-42

Lindgren, Carl-Johan, Gillian G. Garcia, and Matthew I. Saal. 1996. Bank Soundness and Macroeconomic Policy. Washington: International Monetary Fund

Pham, Thi Hong Hanh. 2015. Determinants of Bank Lending. Terdapat di website: https://hal.archives-overtes.fr/hal-01158241/document (Akses pada 26 September 2019).

Pruteanu-Podpiera, Anca Maria. 2007. The role of banks in the Czech monetary policy transmission mechanism. Economics of Transition 15: 393-428

Sakiru A. Solarin, Shawkat Hammoudeh, and Muhammad Shahbaz. (2018). Influence of Economic Factors on Disanggegated Islamic Banking Deposits: Evidence with Structural Breaks in Malaysia. Journal of International Finance Markets, Institutions and Money 55, 13-28.

Setyowati, Nur, 2019, Macroenomic Determinants of Islamic Banking Products in Indonesia, Economies Articels.

Solarin, Sakiru A., Shawkat Hammoudeh, and Muhammad Shahbaz. 2018. Influence of 
Economic Factors on Disaggregated Islamic Banking Deposits: Evidence with Structural Breaks in Malaysia. Journal of International Financial Markets, Institutions and Money 55: 13-28

Sugiyono. (2010). Metode Penelitian Pendidikan (Pendekatan Kualitatif, Kuantitatif dan R\&D). Bandung: Alfabeta.

Bohachova, Olga. 2008. The Impact of Macroeconomic Factors on Risks in the Banking Sector: A Cross-Country Empirical Assessment. Tübingen: Institut für Angewandte Wirtschaftsforschung (IAW), p. 44.

Pruteanu-Podpiera, Anca Maria. 2007. The role of banks in the Czech monetary policy transmission mechanism. Economics of Transition 15: 393-428.

Karim, Adimarwan Azwar. 2010. Ekonomi Makro Islam. Jakarta: PT Raja Grafindo Persada, Edisi Kedua.

Shamsun Nahar, dan Niluthpaul Sarker. 2016. Are Macroeconomic Factors Substantially Influential For Islamic Bank Financing? Cross-Country Evidence. IOSR Journal of Business and Management, Volume 18, Issue 6. Ver 1: PP 20-27.

Syukuri, Ahmad Rifai. 2017. Analisis Pengaruh Kurs Rupiah, Laju Inflasi, Jumlah Uang Beredar, dan Pertumbuhan Ekspor terhadap Total Pembiayaan Perbankan Syariah dengan Dana Pihak Ketiga sebagai Variabel Moderating. Jurnal Ekonomi dan Perbankan Syariah Muqtasid 8

Irfan Syauqi Beik dan Sri Wulan Fatmawati, "Pengaruh Indeks Harga Saham Syariah Internasional dan Variabel Makroekonomi Terhadap Jakarta Islamic Index". Jurnal Al- Iqtisadh: Vol. VI No.2 Juli 2014.

Andrian Tony Prakoso, Analisis Hubungan Perdagangan Internasional dan FDI Terhadap Pertumbuhan Ekonomi Indonesia, Skripsi Universitas Indonesia, 2009.

Dea Rizki Kusmana, Efektivitas Kebijakan Moneter dalam Struktur Pasar Industri Perbankan Indonesia yang Oligopoli, Skripsi IPB, 2013

Agus, Widarjono, "Ekonometrika Teori dan Aplikasi". Yogyakarta: Ekonisia FE UII, 2007

Leni, Setiowati, "Analisis Pengaruh Variabel Ekonomi dan Faktor Demografi Terhadap Tabungan Masyarakat dalam Bentuk Deposito di Perbankan Syariah Indonesia Periode 1981 - 2010", Skripsi, UNAIR, 2013

D.Y. Tulak \& I.T. Utami . (2017). enerapan Autoregressive Distributed Lag (ARDL) Dalam Memodelkan Pengaruh Indeks Harga Konsumen (IHK) Kelompok Bahan Makanan dan Kelompok Makanan Jadi Terhadap Inflasi di Kota Palu An Application of Autoregressive Distributed Lag (ARDL) to The Consu. Journal of Science and Thecnology, 313 - 320.

H. A. Bekhet \& R.W. Al-Smadi. (2015). Determinants of Jordanian foreign direct investment inflows: Bounds testing approach. Economic Modelling, 46, , 27 - 35.

M. B. Shresta \& G.R.Bhatta. (2018). Selecting appropriate methodological framework for time series data analysis. The Journal of Finance and Data Science, 4(2), 71 89. 